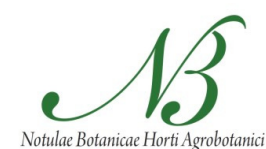

Clij-Napoca

\title{
Non-target Bark Beetles in Ips duplicatus (Sahlberg) Pheromone Traps Baited with Host Volatiles
}

\author{
Mihai-Leonard DUDUMAN ${ }^{1}$, Nicolai OLENICI ${ }^{2}$ \\ 1"Ştefan cel Mare"University of Suceava, Forestry Faculty, Applied Ecology Laboratory, Universității Street 13, Suceava, Romania; mduduman@usv.ro \\ ${ }^{2}$ National Institute of Research and Development in Silviculture "Marin Drăcea", Calea Bucovinei 73 bis, \\ Câmpulung Moldovenesc, Romania; olenicifp@yahoo.com
}

\begin{abstract}
Response of several non-target bark beetles (Coleoptera: Curculionidae, Scolytinae) to different combinations of the northern spruce bark beetle's synthetic pheromone with the monoterpenes (-)-alpha-pinene and (+)-limonene has been studied in choice experiments in the field with flight barrier traps. The experiments were organized in four Norway spruce stands (40-50 years old) outside its natural area, in the north-east of Romania, where Ips duplicatus (Sahlberg) populations had reached an epidemical level. Each experiment had five treatments randomly replicated in six blocks within each experimental plot. Four non-target bark beetle species were captured together with Ips duplicatus: I. typographus (L.) (2611 beetles), Pityogenes chalcographus (L.) (184 beetles), Hylastes cunicularius Erichson (107 beetles) and Dryocoetes autographus (Ratzeburg) (24 beetles), representing 1.77\%, 0.13\%, 0.07\% and $0.02 \%$ respectively of total captures. Beetles of I. typographus were attracted by synthetic pheromone blend of $I$. duplicatus and have intensified their response in the presence of (-)-alphapinene or a combination between (-)-alpha-pinene and (+)-limonene, but the other species have been captured in the traps accidentally. The positive response of I. typographus to the present formulation of $I$. duplicatus pheromone suggests the possibility to use the pheromone dispensers for both species in the same traps when mass-trapping is the main goal, but new studies should clarify the real effects of putting together pheromone dispensers of I. typographus or P. chalcographus with those of I. duplicatus.
\end{abstract}

Keywords: by-catches, northern spruce bark beetle, synthetic attractants, (-)-alpha-pinene, (+)-limonene

\section{Introduction}

Since 1990, the northern spruce bark beetle, Ips duplicatus (Sahlberg), has become an important pest of Norway spruce stands not only in the Central Europe (Grodzki, 1997; Holuša et al., 2013), but also in Romania (Olenici et al., 2011). This process has urged researchers to come up with means for monitoring and control of its populations. Pheromone traps have been usually used for monitoring or mass-trapping bark beetles (Gitau et al., 2013), but frequently many non-target species are captured, either accidentally or as response to different pheromone components (Babuder et al., 1996; Valkama et al., 1997; Schmidt et al., 1999). Mainly, the non-target species are bark beetles that share some pheromone components with the target species (Mendel, 1988). Nevertheless, semiochemicals released from traps are also used as kairomones by competitor species, like woodboring beetles in the genus Monochamus Dejan (Allison et al., 2001, 2004) or by predators, mainly clerid, histerid and nitidulid beetles (Bakke and Kvamme, 1981; Hansen, 1983; Avtzis, 1991). The number of non-target species captured is even higher when host volatiles are associated to pheromone baits (Miller et al., 2011; Panzavolta et al., 2014), because host volatiles are used by many species as kairomones to find their oviposition substrate or their prey. Consequently, knowing which non-target species respond to different pheromone lures or combinations of pheromone and host volatiles may be relevant to understand the chemical ecology of different insect species, to study the abundance of the bark beetle predators (Williams et al., 2009; Sharon et al., 2012), to selectively remove pests (Aukema et al., 2000; Dahlsten et al., 2003 ), or to simultaneously attract a variety of target pest species (Hanks et al., 2012).

There are several studies on the pheromones of $I$. duplicatus (Bakke, 1975; Byers et al., 1990; Schlyter et al., 1992; Ivarsson et al., 1993; Ivarsson and Birgersson, 1995) and their use in forest protection (Schlyter et al., 2001), but none considering the non-target species attracted by synthetic pheromones of this species. This is the reason to present in this paper the data on non-target scolytine species caught during field tests concerning the response of I. duplicatus to different combinations of synthetic pheromone with (-)alpha-pinene and (+)-limonene that was presented in a previous paper (Duduman, 2014). 
Table 1. The treatments used in the experiments [Id - ipsdienole, EM - E-myrcenole, MB - methyl-buthenole, AP - (-)-alpha-pinene), L-(+)-limonene]

\begin{tabular}{|c|c|c|}
\hline Treatment & Specification of dispensers (composition and release rates) & $\begin{array}{l}\text { Ration of pheromone to monoterpenes } \\
\qquad(\mathrm{Id}+\mathrm{EM}): \mathrm{AP}: \mathrm{L}\end{array}$ \\
\hline \multicolumn{3}{|c|}{ Experiment 1: May 16 - June 3, 2011} \\
\hline V1.1 & [1Id:1EM:38MB] $20 \mathrm{mg} /$ day & $1: 0: 0$ \\
\hline V1.2 & [1Id:1EM:38MB] $20 \mathrm{mg} /$ day+ [AP] $40 \mathrm{mg} /$ day & $1: 40: 0$ \\
\hline V1.3 & [1Id:1EM:38MB] $20 \mathrm{mg} /$ day $+[\mathrm{AP}] 200 \mathrm{mg} /$ day & 1: $200: 0$ \\
\hline V1.4 & [1Id:1EM:38MB] $20 \mathrm{mg} /$ day $+[\mathrm{AP}] 1000 \mathrm{mg} /$ day & $1: 1000: 0$ \\
\hline V1.5 & control (blank) & $0: \quad 0: \quad 0$ \\
\hline \multicolumn{3}{|c|}{ Experiment 2: June 24 - July 10, 2011} \\
\hline V2.1 & [1Id:1EM:38MB] $20 \mathrm{mg} /$ day & $1: \quad 0: 0$ \\
\hline V2.2 & [1Id:1EM:38MB] $20 \mathrm{mg} /$ day + [L] $40 \mathrm{mg} /$ day & $1: \quad 0: 40$ \\
\hline V2.3 & [1Id:1EM:38MB] $20 \mathrm{mg} /$ day + [L] $200 \mathrm{mg} /$ day & 1: $\quad 0: 200$ \\
\hline V2.4 & [1Id:1EM:38MB] $20 \mathrm{mg} /$ day $+[\mathrm{L}] 1000 \mathrm{mg} /$ day & $1: \quad 0: 1000$ \\
\hline V2.5 & control (blank) & $0: \quad 0: 0$ \\
\hline \multicolumn{3}{|c|}{ Experiment 3: July 16-28, 2011} \\
\hline V3.1 & [1Id:1EM:38MB] $20 \mathrm{mg} /$ day & $1: \quad 0: 0$ \\
\hline V3.2 & [1Id:1EM:38MB] $20 \mathrm{mg} /$ day $+[\mathrm{AP}] 40 \mathrm{mg} /$ day + [L] $40 \mathrm{mg} /$ day & 1: $\quad 40: 40$ \\
\hline V3.3 & [1Id:1EM:38MB] $20 \mathrm{mg} /$ day + [AP] $200 \mathrm{mg} /$ day + [L] $200 \mathrm{mg} /$ day & $1: 200: 200$ \\
\hline V3.4 & [1Id:1EM:38MB] $20 \mathrm{mg} /$ day + [AP] $1000 \mathrm{mg} /$ day $+[\mathrm{L}] 1000 \mathrm{mg} /$ day & $1: 1000: 1000$ \\
\hline V3.5 & control (blank) & $0: \quad 0: 0$ \\
\hline \multicolumn{3}{|c|}{ Experiment 4: May 19 - June 19, 2012} \\
\hline V4.1 & [1Id:1EM:38MB] $20 \mathrm{mg} /$ day & $1: \quad 0: 0$ \\
\hline V 4.2 & [1Id:1EM:18MB] $20 \mathrm{mg} /$ day & $2: \quad 0: 0$ \\
\hline V4.3 & [1Id:1EM:38MB:1AP:1L] 20 mg/day & $1: \quad 1: \quad 1$ \\
\hline V4.4 & [1Id:1EM:18MB:0,5AP:0,5L] $20 \mathrm{mg} /$ day & $2: 1: 1$ \\
\hline V4.5 & [1Id:1EM:18MB:1AP:1L] $20 \mathrm{mg} /$ day & $2: \quad 2: \quad 2$ \\
\hline
\end{tabular}

\section{Materials and Methods}

As all details concerning the material and methods were published with the main results of the experiments (Duduman, 2014), the present study has been focused on those elements necessary for understanding the results concerning non-target bark beetles.

\section{Experimentalsite}

The data were produced by four experiments deemed to evaluate the response of $I$. duplicatus to different combinations of synthetic pheromone, alpha-pinene (AP) and limonene (L). These experiments were conducted during the spring and the summer of 2011 and 2012, in four areas with pure Norway spruce stands (4050 years old) growing outside the natural area of the species, in the north-eastern Romania (Suceava county), where I. duplicatus populations have already reached an epidemical level in the previous years. The experiments were installed in clear-cut areas, along the edges of the stands. The first three experiments (Table 1) were conducted in 2011 in the plots Zamostea $\left(47^{\circ} 52^{\prime} 46.31^{\prime \prime N}\right.$; $26^{\circ} 08^{\prime} 33.38^{\prime \prime} \mathrm{E} ; 375 \mathrm{~m}$ a.s.l.); Calafindești $\left(47^{\circ} 51^{\prime} 05.11^{\prime \prime N}\right.$; $26^{\circ} 08^{\prime} 46.97^{\prime \prime} \mathrm{E} ; 490 \mathrm{~m}$ a.s.l) and Feteşti $\left(47^{\circ} 43^{\prime} 04.52^{\prime \prime} \mathrm{N}\right.$; $26^{\circ} 19^{\prime 2} 28.88^{\prime \prime} \mathrm{E} ; 400 \mathrm{~m}$ as.l.), while the $4^{\text {th }}$ was conducted in 2012 , in the experimental plots Calafindeşti, Feteşti and Mitocaş (4744'58.70"N;26 $15^{\prime} 16.87^{\prime \prime} \mathrm{E} ; 440$ mas.l.).

\section{Experimentaldesign}

The experimental design was the same for all four experiments. Each experiment had five treatments randomly replicated in six blocks within each experimental plot. In order to reduce the influence of the trap position over the insects captures, the treatments were moved by one position within each block observing the four permutations conceived for each experiment.

The synthetic lures used as treatments were installed in flight intercept traps. The traps were placed at $15 \mathrm{~m}$ from each other and 12 $14 \mathrm{~m}$ from the forest edge. The minimum distance between two blockswas $15 \mathrm{~m}$.
The treatments in experiments 1-3 combined various synthetic pheromone compounds (ipsdienole (Id), E-myrcenole (EM) and methyl-buthenole $(\mathrm{MB})$ in ratio $1 \mathrm{Id}: 1 \mathrm{EM}: 38 \mathrm{MB}$ ) released at constant rate, and terpenes (AP and L, each released at different rates) (Table 1).In the $4^{\text {th }}$ experiment the treatments consisted of mixtures of pheromone and terpenes, released at a constant rate from the same dispenser, the differences between treatments being achieved by changing the ratios of the pheromone components and terpenes (Table 1).

As described by Duduman (2014), the pheromone and alphapinene dispensers used in the experiments have been made from polyethylene envelopes with different dimensions. Each envelope contained a cellulosic support impregnated with the mixture of pheromone components or with alpha-pinene. The limonene dispensers consisted of polypropylene bottles, which contained similar cellulosic supports for the active compound.

\section{Collection and processing of captured insects}

The insects captured in the traps were collected at every $3-4$ days in experiments 1-3 and at 7 days in experiment 4 . Afterward the captures were stored in a freezer awaiting laboratory analyses, which consisted in sorting, identifying and counting the bark beetles.

\section{Data analysis}

In order to find out the differences between the blocks and the treatments, the data concerning I. typographus (L.) were analysed by ANOVA at confidence level of $95 \%$. The very low number of beetle captures from other species precluded further statistical analysis. There were less than 100 beetles cumulated per experiment and area, equivalent to 20 insects per treatment. The homogeneity of variances has been tested using the Hartley test, and, when necessary, the data where logtransformed $\left(\mathrm{x}^{\prime}=\log (\mathrm{x}+1)\right)$ to obtain homogenous variances. When the homogeneity was not confirmed, the heterogeneous population of data that induced inhomogeneity was eliminated from analyses. 
Table 2. Total number of bark beetles captured in each experiment

\begin{tabular}{|c|c|c|c|c|c|}
\hline Location & $\begin{array}{c}\text { Ips } \\
\text { duplicatus }\end{array}$ & $\begin{array}{c}\text { Ips } \\
\text { typographus }\end{array}$ & $\begin{array}{c}\text { Pityogenes } \\
\text { chalcographus }\end{array}$ & $\begin{array}{c}\text { Hylastes } \\
\text { cunicularius }\end{array}$ & $\begin{array}{c}\text { Dryocoetes } \\
\text { autographus }\end{array}$ \\
\hline \multicolumn{6}{|l|}{ Experiment 1} \\
\hline Zamostea & 4662 & 230 & 15 & 13 & 2 \\
\hline Calafindeşti & 3105 & 479 & 24 & 47 & 6 \\
\hline Feteşti & 1675 & 194 & 12 & 42 & 1 \\
\hline \multicolumn{6}{|l|}{ Experiment 2} \\
\hline Zamostea & 21700 & 35 & 22 & 0 & 0 \\
\hline Calafindeşti & 27861 & 121 & 17 & 0 & 0 \\
\hline Feteşti & 13843 & 101 & 9 & 0 & 0 \\
\hline \multicolumn{6}{|l|}{ Experiment 3} \\
\hline Zamostea & 10085 & 19 & 14 & 0 & 0 \\
\hline Calafindeşti & 3563 & 314 & 7 & 0 & 0 \\
\hline Feteşti & 2000 & 106 & 21 & 0 & 0 \\
\hline \multicolumn{6}{|l|}{ Experiment 4} \\
\hline Mitocaş & 22737 & 411 & 3 & 2 & 6 \\
\hline Calafindeşti & 17961 & 586 & 22 & 2 & 7 \\
\hline Feteşti & 14999 & 15 & 18 & 1 & 2 \\
\hline
\end{tabular}

Table 3. ANOVA results of the effects of treatments and blocks, as well as their interactions on I. typographus captures (DF - degrees of freedom, F - Fisher's test, P - the probability that the null hypothesis is true)

\begin{tabular}{|c|c|c|c|c|c|c|c|c|c|}
\hline \multirow{2}{*}{ Statistical value } & \multicolumn{3}{|c|}{ Zamostea/Mitocaş } & \multicolumn{3}{|c|}{ Calafindeşti } & \multicolumn{3}{|c|}{ Feteşti } \\
\hline & DF & $\mathrm{F}$ & $\mathrm{P}$ & DF & $\mathrm{F}$ & $\mathrm{P}$ & DF & $\mathrm{F}$ & $\mathrm{P}$ \\
\hline \multicolumn{10}{|l|}{ Experiment 1} \\
\hline Treatment & 3 & 21.028 & $<0.001$ & 3 & 4,162 & 0.045 & 3 & 0.571 & 0.643 \\
\hline Block & 5 & 12.373 & $<0.001$ & 5 & 2.807 & 0.055 & 5 & 5.267 & 0.005 \\
\hline Treatment x Block & 15 & 1.801 & 0.099 & 15 & 3.128 & 0.095 & 15 & 1.256 & 0.116 \\
\hline \multicolumn{10}{|l|}{ Experiment 2} \\
\hline Treatment & - & - & - & 3 & 1.447 & 0.282 & 3 & 1.058 & 0.431 \\
\hline Block & - & - & - & 5 & 7.531 & $<0.001$ & 5 & 9.526 & $<0.001$ \\
\hline Treatment x Block & - & - & - & 15 & 1.643 & 0.276 & 15 & 1.303 & 0.108 \\
\hline \multicolumn{10}{|l|}{ Experiment 3} \\
\hline Treatment & - & - & - & 3 & 12.871 & $<0.001$ & 3 & 4.972 & 0.003 \\
\hline Block & - & - & - & 5 & 8.682 & $<0.001$ & 5 & 3.097 & 0.031 \\
\hline Treatment $\mathrm{x}$ Block & - & - & - & 15 & 1.807 & 0.090 & 15 & 0.824 & 0.569 \\
\hline \multicolumn{10}{|l|}{ Experiment 4} \\
\hline Treatment & 4 & 0.776 & 0.554 & 4 & 0.419 & 0.793 & - & - & - \\
\hline Block & 5 & 6.611 & 0.001 & 5 & 22.511 & $<0.001$ & - & - & - \\
\hline Treatment x Block & 20 & 1.591 & 0.083 & 20 & 1.187 & 0.245 & - & - & - \\
\hline
\end{tabular}

The normality of the distributions was tested using the Shapiro-Wilk test. When significant differences were found, Tukey's honest significant difference for multiple comparison test was applied for the mean separation. All statistical computations were done using XLSTAT-Pro 2012 software, plugged into MS Excel.

\section{Results}

Four non-target bark beetle species were captured together with I. dupicatus: I. typographus ( $\mathrm{n}=2611$ beetles), Pityogenes chalcographus (L.) ( $\mathrm{n}=184$ beetles), Hylastes cunicularius Erichson ( $\mathrm{n}=107$ beetles) and Dryocoetes autographus (Ratzeburg) ( $\mathrm{n}=24$ beetles) (Table 2), representing $1.77 \%$, $0.13 \%, 0.07 \%$ and $0.02 \%$ respectively of total captures.

Most I. typographus beetles have been captured at Calafindeşti (all experiments) and the least at Zamostea (experiments 2-3) and Fetești (experiments 1 and 4), reflecting the variations of population level between the three locations.

$P$. chalcographus was captured in all experimental areas, and in all experiments. In general the differences between captures in experimental areas or experiments are small. H. cunnicularius and D. autographus have been captured in all experimental areas, but only in experiments 1 and 4 . Most of individuals of the first and the second aforementioned species were found on the experiment 1 and 4, respectively (Table 2).
Analyses concerning the influence of the different factors (treatment and experimental block) on the responses of bark beetles associated with $I$. duplicatus were conducted only for $I$. typographus, when the number of captures exceeded 100 insects. The block position significantly influenced $I$. typographus response in almost all situations (except for the $1^{\text {st }}$ experiment at Calafindești). A statistically significant influence of the treatments on the I. typographus response was found only for experiment 1, at Zamostea and Calafindeşti, and in experiment 3 at Calafindeşti and Feteşti (Table 3).

The treatments generated different responses in associated bark beetles species. In the $1^{\text {st }}$ experiment, the beetles responded intensely to the treatments with AP (V1.2, V1.3) within the experimental areas Zamostea and Calafindeşti. These treatments attracted more beetles than the treatment without $\mathrm{AP}(\mathrm{V} 1.1)$ or the treatment with high release rate of $\mathrm{AP}(\mathrm{V} 1.4)$. The presence of $\mathrm{L}$ alongside the pheromone lures in the treatments V2.2, V2.3 and V2.4 (experiment 2) did not lead to a different response of $I$. typographus beetles compared with the one from pheromone lure (V2.1), and only the blank traps have captured significantly fewer beetles. Adding both $\mathrm{AP}$ and $\mathrm{L}$ to the pheromone (experiment 3) has increased the captures of I. typographus. The number of captures has also increased, as the terpene released rates has increased from 40 to $1000 \mathrm{mg} /$ day (expected rates). A significant increase of attractiveness has been observed only by increasing the release rates of monoterpenes to at least $200 \mathrm{mg} /$ day 
Table 4. Response of the non-target bark beetles to the tested treatments

\begin{tabular}{|c|c|c|c|c|c|c|c|c|c|c|c|c|}
\hline \multirow{3}{*}{ Treatment } & \multicolumn{12}{|c|}{ Number of captured bark beetles/trap (mean \pm SEM $)$} \\
\hline & \multicolumn{3}{|c|}{ Ips typographus } & \multicolumn{3}{|c|}{ Pityogenes chalcographus } & \multicolumn{3}{|c|}{ Hylastes cunicularius } & \multicolumn{3}{|c|}{ Dryocoetes autographus } \\
\hline & $\begin{array}{c}\text { Zamostea/ } \\
\text { Mitocaş }\end{array}$ & Calafindeşti & Feteşti & $\begin{array}{c}\text { Zamostea/ } \\
\text { Mitocaş }\end{array}$ & Calafindeşti & Feteşti & $\begin{array}{c}\text { Zamostea/ } \\
\text { Mitocaş }\end{array}$ & $\begin{array}{l}\text { Calafin- } \\
\text { deşti }\end{array}$ & Feteşti & $\begin{array}{c}\text { Zamostea/ } \\
\text { Mitocaş }\end{array}$ & $\begin{array}{c}\text { Calafin- } \\
\text { deşti }\end{array}$ & Feteşti \\
\hline \multicolumn{13}{|l|}{ Experiment 1} \\
\hline V1.1 & $3.9 \pm 1.1^{\mathrm{b}}$ & $16.8 \pm 5.2^{\mathrm{b}}$ & $7.2 \pm 6.4^{a}$ & $0.7 \pm 0.6$ & $0.4 \pm 0.2$ & $0.3 \pm 0.1$ & $0.2 \pm 0.1$ & $1.5 \pm 0.9$ & $2.0 \pm 1.5$ & - & $0.1 \pm 0.1$ & - \\
\hline V1.2 & $17.5 \pm 4.9^{\mathrm{a}}$ & $27.0 \pm 4.1^{\mathrm{a}}$ & $9.3 \pm 6.9^{\mathrm{a}}$ & $0.4 \pm 0.3$ & $0.9 \pm 0.7$ & $0.1 \pm 0.1$ & $0.2 \pm 0.1$ & $1.4 \pm 1.2$ & $1.2 \pm 0.8$ & - & $0.2 \pm 0.1$ & - \\
\hline V1.3 & $15.3 \pm 4.0^{\mathrm{a}}$ & $27.8 \pm 6.5^{a}$ & $8.3 \pm 3.7^{\mathrm{a}}$ & $0.2 \pm 0.1$ & $1.0 \pm 0.8$ & $0.4 \pm 0.3$ & $0.5 \pm 0.3$ & $0.9 \pm 0.6$ & $1.9 \pm 1.2$ & - & $0.3 \pm 0.2$ & - \\
\hline V1.4 & $4.5 \pm 2.1^{b}$ & $8.17 \pm 1.9^{b}$ & $7.5 \pm 4.1^{a}$ & $0.8 \pm 0.6$ & $0.4 \pm 0.3$ & $0.6 \pm 0.4$ & $0.7 \pm 0.5$ & $3.8 \pm 1.9$ & $1.5 \pm 1.1$ & $0.2 \pm 0.1$ & - & $0.2 \pm 0.2$ \\
\hline V1.5 & $0.3 \pm 0.2^{c}$ & $0.8 \pm 0.5^{c}$ & $0.2 \pm 0.1^{b}$ & $0.2 \pm 0.2$ & $0.8 \pm 0.6$ & $0.5 \pm 0.4$ & $0.6 \pm 0.5$ & $0.4 \pm 0.4$ & $1.2 \pm 0.8$ & - & $0.2 \pm 0.2$ & - \\
\hline \multicolumn{13}{|l|}{ Experiment 2} \\
\hline V2.1 & $1.8 \pm 1.2$ & $7.3 \pm 2.7^{a}$ & $7.5 \pm 4.7^{a}$ & $1.2 \pm 0.7$ & $0.2 \pm 0.1$ & $0.4 \pm 0.3$ & - & - & - & - & - & - \\
\hline V2.2 & $1.7 \pm 1.1$ & $4.5 \pm 1.8^{\mathrm{a}}$ & $4.3 \pm 2.6^{a}$ & $0.2 \pm 0.1$ & $0.9 \pm 0.7$ & $0.1 \pm 0.1$ & - & - & - & - & - & - \\
\hline V2.3 & $1.5 \pm 0.6$ & $3.0 \pm 1.3^{a}$ & $2.8 \pm 1.5^{a}$ & $0.6 \pm 0.4$ & $0.2 \pm 0.2$ & $0.5 \pm 0.3$ & - & - & - & - & - & - \\
\hline V2.4 & $0.7 \pm 0.6$ & $2.1 \pm 0.8^{a}$ & $1.5 \pm 1.3^{\mathrm{a}}$ & $0.7 \pm 0.3$ & $1.1 \pm 0.8$ & $0.1 \pm 0.1$ & - & - & - & - & - & - \\
\hline V2.5 & $0.2 \pm 0.2$ & $0.1 \pm 0.1^{b}$ & $0.3 \pm 0.2^{b}$ & $0.5 \pm 0.4$ & $0.5 \pm 0.4$ & $0.1 \pm 0.1$ & - & - & - & - & - & - \\
\hline \multicolumn{13}{|l|}{ Experiment 3} \\
\hline V3.1 & $0.2 \pm 0.1$ & $4.2 \pm 1.8^{b}$ & $1.0 \pm 0.5^{b}$ & $0.4 \pm 0.3$ & $0.2 \pm 0.1$ & $0.9 \pm 0.7$ & - & - & - & - & - & - \\
\hline V3.2 & $0.3 \pm 0.2$ & $4.2 \pm 2.4^{b}$ & $2.8 \pm 1.3^{b}$ & $0.6 \pm 0.4$ & $0.5 \pm 0.3$ & $0.6 \pm 0.5$ & - & - & - & - & - & - \\
\hline V3.3 & $1.2 \pm 0.3$ & $20.7 \pm 7.8^{a}$ & $6.7 \pm 2.6^{a}$ & $0.3 \pm 0.2$ & $0.1 \pm 0.1$ & $1.0 \pm 0.8$ & - & - & - & - & - & - \\
\hline V3.4 & $1.7 \pm 0.4$ & $23.3 \pm 7.3^{a}$ & $7.2 \pm 3.3^{a}$ & $0.5 \pm 0.4$ & $0.4 \pm 0.2$ & $0.8 \pm 0.5$ & - & - & - & - & - & - \\
\hline V3.5 & $0.1 \pm 0.0$ & $0.1 \pm 0.1^{\mathrm{c}}$ & $0.2 \pm 0.1^{c}$ & $0.3 \pm 0.3$ & $0.1 \pm 0.1$ & $0.2 \pm 0.1$ & - & - & - & - & - & - \\
\hline \multicolumn{13}{|l|}{ Experiment 4} \\
\hline V4.1 & $13.6 \pm 3.9^{a}$ & $17.7 \pm 7.0^{\mathrm{a}}$ & $0.5 \pm 0.3$ & $0.0 \pm 0.0$ & $0.5 \pm 0.4$ & $0.9 \pm 0.8$ & - & $0.2 \pm 0.1$ & - & $0.3 \pm 0.2$ & $0.2 \pm 0.1$ & - \\
\hline V4.2 & $10.0 \pm 1.8^{a}$ & $23.0 \pm 11.4^{a}$ & $0.2 \pm 0.2$ & $0.1 \pm 0.1$ & $1.1 \pm 0.8$ & $0.3 \pm 0.2$ & $0.2 \pm 0.1$ & - & - & $0.2 \pm 0.2$ & $0.5 \pm 0.5$ & - \\
\hline V4.3 & $19.5 \pm 6.3^{a}$ & $15.7 \pm 6.9^{\mathrm{a}}$ & $0.5 \pm 0.4$ & $0.0 \pm 0.0$ & $0.7 \pm 0.5$ & $0.5 \pm 0.4$ & - & $0.1 \pm 0.1$ & - & $0.2 \pm 0.1$ & $0.4 \pm 0.3$ & - \\
\hline V4.4 & $15.6 \pm 4.1^{\mathrm{a}}$ & $14.7 \pm 6.5^{a}$ & $1.0 \pm 0.5$ & $0.3 \pm 0.2$ & $1.0 \pm 0.9$ & $0.2 \pm 0.2$ & $0.1 \pm 0.1$ & - & $0.1 \pm 0.1$ & $0.1 \pm 0.1$ & $0.2 \pm 0.1$ & - \\
\hline V4.5 & $10.0 \pm 2.7^{\mathrm{a}}$ & $26.7 \pm 10.7^{a}$ & $0.3 \pm 0.2$ & $0.2 \pm 0.1$ & $0.3 \pm 0.2$ & $0.9 \pm 0.7$ & - & $0.1 \pm 0.1$ & - & $0.2 \pm 0.2$ & - & - \\
\hline
\end{tabular}

comparison test). Values that are not followed by letters were not subjected to statistical analysis.

(V3.3 and V3.4) (Calafindești and Fetești). Also, significantly fewer beetles have been captured in blank traps (V3.5) than in baited ones. In experiment 4, the response of I. typographus beetles has not been modified by doubling the release rates of pheromone components and adding small quantities of AP and $\mathrm{L}$.

As for $P$. chalcographus, the captures were low regardless of the experiment, treatment or experimental area, and the blank traps captured similar numbers of beetles as did the baited traps. $H$. cunicularius has also been scantily captured in all treatments tested in experiment 1 and in all experimental areas, without any preference. In the experiment 4, the small captures of $H$. cunicularius were quite irregularly distributed between treatments and experimental areas, not indicating any tendency of beetle response to treatments. D. autographus beetles were caught in experiment 1 (mainly at Calafindeşti) and experiment 4 (Zamostea and Calafindești), and the distribution of captures between the treatments does not indicate a preference of this species for any tested volatile mixtures (Table 4).

\section{Discussion}

Even though I. typographus captures were proportionally small, this species was clearly attracted by pheromone lures in the first three experiments, and this response was expected due to the presence of $\mathrm{MB}$ and Id in the lure composition. Both substances are pheromone components of the European spruce bark beetle (Bakke, 1976; Bakke et al., 1977). On the other hand, the small captures of this species reflect not only the lower level of $I$. typographus populations comparing with I. duplicatus, but also the inhibitory effect of EM at high release rates of other pheromone components, as already noted Schlyter et al. (1992).

Adding the terpenes to the pheromone lures has increased $I$. typographus captures. The intensification of this species response to the pheromone in the presence of AP was showed by Erbilgin et al. (2007), who used as pheromone components only MB and cis- verbenol. However, in the presence of high release rates of AP with ( $945.5 \mathrm{mg} /$ day), in our experiments, I. typographus responded to the same extent as to the pheromone alone. The high concentration of terpenes did not induce any reaction on bark beetles. A higher rate of AP might have induced a reduced response, as noted in other research (Olenici et al., 2007). Likewise I. duplicatus (Duduman, 2014), the L presence has not affected I. typographus response to pheromones, confirming the results obtained by Reddeman and Schopf (1996). The intensification of I. typographus response to pheromone in the presence of both monoterpenes $(\mathrm{AP}+\mathrm{L})$ is supported by the results of previous researches (Reddeman and Schopf, 1996; Hulcr et al., 2006), which revealed a similar behaviour when the specific pheromone for this species was used.

The small number of $P$. chalcographus captured and the similarity of its response to all tested treatments (including the blank traps) show that the individuals of this species might have entered accidentally into the traps, without being attracted by the volatile combinations. Moreover, in other experiments it was found that the presence of $\mathrm{AP}$ (released with approx. $170 \mathrm{mg} /$ day) did not lead to changes of $P$. chalcographus response to a specific pheromone (Niemayer and Watzek, 1996).

$H$. cunicularius and $D$. autographus were captured in small numbers and only in the experiments where no treatments with $\mathrm{L}$ were used. From previous studies it is known that the first species is not attracted by AP alone, but by a mixture of terpene and ethanol (Schroeder and Lindelöw, 1989; Lindelöw et al., 1993), while D. autographus is attracted by a mixture of AP and pheromone component ex-brevicomin (Gandhi et al., 2009). Also, both species are attracted by host volatiles released by the stored spruce material (Lindelöw and Risberg, 1992; Tunset et al., 1993), especially from tree roots (Eidmann et al., 1991).

The lack of $H$. cunicularius captures in the $2^{\text {nd }}$ and the $3^{\text {rd }}$ experiment could also be a result of the differences between the flight patterns of this species and the other ones, $H$. cunicularius 
$\mathrm{X}$

flying earlier, especially at low altitudes, mainly in April (Postner, 1974), while I. typographus, I. duplicatus, P. chalcographus and $D$. autographus are flying in midsummer and all of them, excepting the last one, have a quite similar pattern of flight activity (Wegensteiner and Führer, 1991; Holuša et al., 2012).

Given our results and considering that the synthetic pheromone of I. typographus attracts many I. duplicatus beetles (Valkama et al., 1997), it would be possible to set in the same traps the pheromone dispensers of both species without affecting the captures of either species, thereby reducing the costs of control when these are the main pests. However, new tests should be conducted to clarify what happens with each species, because high release rates of EM inhibit the response of I. typographus males (Schlyter et al., 1992). Also, new studies are necessary to determine what happens if synthetic pheromone of $I$. duplicatus is used together with that of $P$. calcographus.

\section{Conclusions}

Among the bark beetle species associated with I. duplicatus, which have been captured in traps baited with tested treatments, only I. typographus has been attracted by synthetic pheromone of $I$. duplicatus and has intensified its response in the presence of (-)alpha-pinene or a combination between (-)-alpha-pinene and (+)limonene. The other species ( $P$. chalcographus, $H$. cunicularius, $D$. autographus) have been captured in the traps almost accidentally.

The positive response of $I$. typographus to the present formulation of I. duplicatus synthetic pheromone suggests the possibility of using pheromone dispensers for both species in the same traps, to reduce the costs of mass-trapping these pests.

\section{Acknowledgments}

This work was supported by a grant received from the Romanian Ministry of Education, CNCS - UEFISCDI, project numbers PN-II-RU-PD-2012-3-0304 and PN II-RU 563/2010. The support in the field from the personnel of Suceava County Branch of the Romanian National Forest Administration Romsilva (Forest Districts Pătrăuți and Adâncata) is greatly appreciated.

\section{References}

Allison JD, Borden JH, McIntosh RL, de Groot P, Gries R (2001). Kairomonal response by four Monochamus species (Coleoptera: Cerambycidae) to bark beetle pheromones. Journal of Chemical Ecology 27(4):633-646.

Allison JD, Borden JH, Seybold SJ (2004). A review of the chemical ecology of the Cerambycidae(Coleoptera). Chemoecology 14:123-150.

Aukema BH, Dahlsten DL, Raffa KF (2000). Exploiting behavioural disparities among predators and prey to selectively remove pests: maximizing the ratio of bark beetles to predators removed during semiochemically based trap-out. Environmental Entomology 29:618629.

Avtzis N (1991). Beifänge in Borkenkäfer-Pheromonfallen in NordGriechenland. [Bycatches in bark beetle pheromone traps in northern Greece]. Anzeiger für Schädlingskunde, Pflanzenschutz, Umweltschutz 64(1):13-14.
Babuder G, Pohleven F, Brelih S (1996). Selectivity of synthetic aggregation pheromones Linoprax and Pheroprax in the control of the bark beetles (Coleoptera, Scolytidae) in a timber storage yard. Journal of Applied Entomology 120:131-136.

Bakke A (1975). Aggregation pheromone in the bark beetle Ips duplicatus (Sahlberg). Norwegian Journal of Entomology 22:67-69.

Bakke A (1976). Spruce bark beetle, Ips typographus: pheromone production and field response to synthetic pheromones. Naturwissenschaften 63:92.

Bakke A, Froyen P, Skattebol L (1977). Field response to a new pheromonal compound isolated from Ips typographus. Naturwissenschaften 64:98.

Bakke A, Kvamme T (1981). Kairomone response in Thanasimus predators to pheromone components of Ips typographus. Journal of Chemical Ecology 7(2):305-312.

Byers JA, Schlyter F, Birgersson G, Francke W (1990). E-mircenol in Ips duplicatus: An aggregation pheromone component new for bark beetles. Experientia 46:1209-1211.

Dahlsten DL, Six DL, Erbilgin N, Raffa KF, Lawson AB, Rowney DL (2003). Attraction of Ips pini (Coleoptera: Scolytidae) and its predators to various enantiomeric ratios of ipsdienol and lanierone in California: implications for the augmentation and conservation of natural enemies. Environmental Entomology 32:1115-1122.

Duduman ML (2014). Field response of the northern spruce bark beetle Ips duplicatus (Sahlberg) (Coleoptera: Curculionidae, Scolytinae) to different combinations of synthetic pheromone with (-)- $\alpha$-pinene and (+)-limonene. Agricultural and Forest Entomology 16(1):102109.

Eidmann HH, Kula E, Lindelow A (1991). Host recognition and aggregation behavior of Hylastes cunicularius Erichson (Col, Scolytidae) in the laboratory. Journal of Applied Entomology 112(1):11-18.

Erbilgin N, Krokene P, Kvamme T, Christiansen E (2007). A host monoterpene influences Ips typographus (Coleoptera: Curculionidae, Scolytinae) responses to its aggregation pheromone. Agricultural and Forest Entomology 9:135-140.

Gandhi KJK, Gilmore DW, Haack RA, Katovich SA, Krauth SJ, Mattson WJ, Zasada JC, Seybold SJ (2009). Application of semiochemicals to assess the biodiversity of insects following an ecosystem disturbance in a sub-boreal forest. Journal ofChemical Ecology35(12):13841410.

Gitau CW, Bashford R, Carnegie AJ, Gurr GM (2013). A review of semiochemicals associated with bark beetle (Coleoptera: Curculionidae: Scolytinae) pests of coniferous trees: A focus on beetle interactions with other pests and their associates. Forest Ecology and Management 297:114.

Grodzki W (1997). Possibilities of the control of double-spined bark beetle Ips duplicatus C. R. Sahlb. populations in southern Poland. Sylwan 141(11):25-36.

Hanks LM, MillarJG, Mongold-Diers JA, WongJCH, Meier LR, Reagel PF, Mitchell RF (2012). Using blends of cerambycid beetle pheromones and host plant volatiles to simultaneously attract a diversity of cerambycid species. Canadian Journal of Forest Research 42(6):1050-1059. 
Hansen K (1983). Reception of bark beetle pheromone in the predaceous clerid beetle, Thanasimus formicarius (Coleoptera: Cleridae). Journal ofComparative Physiology 150:371-378.

Holuša J, Lukášová K, LubojackýJ (2012). Comparison of seasonal flight activity of Ips typographus and Ips duplicatus. Scientia Agriculturae Bohemica 43(3):109-115.

Holuša J, Lukášová K, Trombik J (2013). The first record of Ips duplicatus (Coleoptera: Curculionidae, Scolytinae) infestations in central European inner mountains. Scientia Agriculturae Bohemica 44(2):97-101.

Hulcr J, Ubik K, VrkočJ (2006). The role of semiochemicals in tri-trophic interactions between the spruce bark beetle Ips typographus, its predators and infested spruce. Journal of Applied Entomology 130(5):275-283.

Ivarsson P, Birgersson G (1995). Regulation and biosynthesis of pheromone components in the double spined bark beetle Ips duplicatus (Coleoptera: Scolytidae). Journal of Insect Physiology 41:843-849.

Ivarsson P, Schlyter F, Birgersson G (1993). Demonstration of de novo pheromone biosynthesis in Ips duplicatus (Coleoptera: Scolytidae): inhibition of ipsdienol and E-myrcenol production by compactin. Insect Biochemistry and Molecular Biology 23:655-662.

Lindelöw A, Eidmann HH, Nordenhem H (1993). Response on the ground of bark beetle and weevil species colonizing conifer stumps and roots to terpenes and ethanol. Journal of Chemical Ecology 19(7):1393-1403.

Lindelöw A, Risberg B (1992). Attraction during flight of scolytids and other bark- and wood-dwelling beetles to volatiles from fresh and stored spruce wood. Canadian Journal of Forest Science 22:224228.

Mendel Z (1988). Attraction of Orthotomicus erosus and Pityogenes calcaratus to a synthetic aggregation pheromone of Ips typographus. Phytoparasitica 16:109-117.

Miller DR, Asaro C, Crowe CM, Duer DA (2011). Bark beetle pheromones and pine volatiles: attractant kairomone lure blend for longhorn beetles (Cerambycidae) in pine stands of the Southeastern United States. Journal of Economic Entomology 104(4):1245-1257.

Niemayer H, Watzek G (1996). Test von Monoterpenen als Zusatz zu Pheroprax bzw. Chalcoprax in Pheromonfallen zum Fang des Buchdruckers,Ips typographus L. bzw. des Kupferstechers,Pityogenes chalcographus L. (Col., Scolytidae) [Test of monoterpenes as an addition to Pheroprax and Chalcoprax, respectively, in pheromone traps for the trapping of the spruce bark beetle, Ips typographus L., and of the engraver, Pityogenes chalcographus L. (Col. Scolytidae)] Anzeiger für Schädlingskunde, Pflanzenschutz, Umweltschutz 69:109-110.

Olenici N, Duduman ML, Olenici V (2007). Inhibitory effect of (-) alphapinene high release rates on Ips typographus (L.) response to its aggregation pheromone. Analele ICAS 50:203-212.

Olenici N, Duduman M-L, Olenici V, Bouriaud O, Tomescu R, Rotariu C (2011). The first outbreak of Ips duplicatus (Coleoptera, Curculionidae, Scolytinae) in Romania. In: Delb H, Pontuali S (Eds). Proceedings of the 10th IUFRO Workshop "Methodology of Forest Insect and Disease Survey in Central Europe”, Sept 20-23, 2010,
Freiburg, Germany. Fakultät für Forst- und Umweltwissenschaften der Albert-Ludwigs-Universität and Forstliche Versuchs- und Forschungsanstalt (FVA), Freiburg in Baden-Württemberg, Germany pp 135-140.

Panzavolta T, Racalini M, Bonuomo L, Croci F, Tiberi R (2014). Field response of non-target beetles to Ips sexdentatus aggregation pheromone and pine volatiles. Journal of Applied Entomology 138(8):586-599.

Postner M (1974). Scolytidae (= Ipidae), bark beetles, p. 334482. In: Schwenke W (Ed). Die Forstschädlinge Europas. 2. Band. Paul Parey, Hamburgund Berlin (in German).

Reddemann J, Schopf R (1996). Zur Bedeutung von Monoterpenen bei der aggregation des Buchdruckers Ips typographus (Coleoptera: Scolytidae: Ipinae) [On the importance of monoterpenes in the aggregation of the spruce bark beetle Ips typographus (Coleoptera: Scolytidae: Ipinae)]. Entomologia Generalis 21(1/2):69-80.

Schlyter F, Birgersson G, Byers JA, Bakke A (1992). The aggregation pheromone of Ips duplicatus and its role in competitive interactions with I. typographus (Coleoptera: Scolytidae). Chemoecology 3(34):103-112.

Schlyter F, Zhang QH, Liu GT, Ji LZ (2001). A successful case of pheromone mass trapping of the bark beetle Ips duplicatus in a forest island, analysed by 20-year time-series data. Integrated Pest Management Reviews 6:185-196.

Schmidt GH, Schmidt L, Mucha H (1999). Fängigkeit von differenziert bestückten Borkenkäferpheromonfallen in einem niedersächsischen Forstgebiet bei Hannover während der Jahre 1992 und 1993. [Effectiveness of differently baited bark beetle pheromone traps in a forested area near Hannover during the years 1992 and 1993]. Anzeiger für Schädlingskunde, Pflanzenschutz, Umweltschutz 72(6):137-152.

Schroeder LM, Lindelöw Å (1989). Attraction of scolytids and associated beetles by different absolute amounts and proportions of $\alpha$-pinene and ethanol. Journal of Chemical Ecology 15(3):807-817.

Sharon JM, Tiina Y, Brian TS, Ronald FB, Matthew PA (2012). Alternate attractors in the population dynamics of a tree-killing bark beetle. Population Ecology 55(1):95.

Tunset K, Nilssen AC, Andersen J (1993). Primary attraction in host recognition of coniferous bark beetles and bark weevils (Col, Scolytidae and Curculionidae). Journal of Applied Entomology 115(2):155-169.

Valkama H, Räty M, Niemela P (1997). Catches of Ips duplicatus and other non-target Coleoptera by Ips typographus pheromone trapping. Entomologica Fennica 8:153-159.

Wegensteiner R, Führer E (1991). F Zur höhenabhängigen Aktivitätsdynamik einiger Nadelholz-Borkenkäfer (Coleoptera, Scolytidae) [Flight activity of some conifer bark beetles in relation to altitude (Coleoptera, Scolytidae)]. Anzeiger für Schädlingskunde, Pflanzenschutz, Umweltschutz 64(2):25-34.

Williams KK, McMillin JD, DeGomez TE (2009). Relative and seasonal abundance of three bark beetle predators (Coleoptera: Trogositidae, Cleridae) across an elevation gradient in ponderosa pine forests of north central Arizona. Western North American Naturalist 69(3):351-363. 